\title{
Impact of Brand Trust and Technology Readiness on the Willingness to Use Autonomous Cars in Brazil
}

\author{
José Carlos Rodrigues, Escola Superior de Propaganda e Marketing, Brazil \\ https://orcid.org/0000-0002-5003-8707 \\ Mateus Canniatti Ponchio, Escola Superior de Propaganda e Marketing, Brazil
}

\begin{abstract}
This study sought to analyse whether brand trust and technology readiness influence the willingness to use (WTU) autonomous vehicles (AVs) in Brazil. A survey was applied with potential consumers, and the results, based on 213 respondents, indicated that there is a strong correlation between brand trust and WTU AVs of the same brand as well as between technology readiness and WTU AVs. When confronted through multiple linear regression, brand trust played a more relevant role than technology readiness over WTU AVs for the 11 brands tested. When comparing information technology companies (ITCs) and automobile manufacturers, while the first have a higher level of average brand trust, the preference in WTU AVs rests on traditional automakers. Thus, the results of this study may contribute on how brand managers could explore their brands strengths in regard to consumer's trust when such products become available in the future.
\end{abstract}

\section{KEYWORDS}

Automotive Industry, Autonomous Cars, Brand Trust, Consumer Behaviour, Technology Readiness Index, Willingness to Use

\section{INTRODUCTION}

The arrival of autonomous cars (AVs) may generate a considerable impact on the secular automotive industry. Researchers on the subject claim that it may be the most disruptive change in this industry since its creation by Karl Benz in 1886 and popularization by Henry Ford (Fagnant and Kockleman, 2015; Cavoli, Phillips, Cohen and Jones, 2017; Burns, Jordan and Scarobough, 2013).

AV development projects are being driven both by companies such as Google, Uber, Intel, Baidu, Apple, and others who are focused on the software intelligence behind the automotive body and in finding a niche to apply their information processing capacity with traditional car manufacturers such as Ford, BMW, Toyota, Volvo, General Motors, among others, who are not interested in becoming hardware suppliers for navigational intelligence incorporated in their vehicles. Also, AV development is being driven by "hybrid companies" for which information technology, connectivity, and automotive engineering are an integrated development. This latter category is represented primarily by Tesla 
Motors as well as by other examples such as Argo.AI and Aurora. Also, there are "under-the-hood" component companies such as Bosch and Aptiv who are seeking to expand their performance in the components that are to be supplied to traditional automakers or new entrants. (Goodall, 2014).

It is assumed that the potential confrontation between companies from different sectors can be influenced by the previous trust consumers have in these brands. On other hand, personal characteristics towards technology could also play a relevant role on potential consumers' willingness to use an incipient technology.

This is the reason why the objective of this study is to confront a innovation adoption model that analyses individual acceptance for new technologies - in particular, the Technology Readiness Index 2.0 (TRI 2.0), by Parasuraman and Colby (2015) - and brand trust measures and to verify the influence of both on the willingness to use (WTU) AVs. The Multidimensional Brand Trust Scale, by Gurviez and Korchia (2003) was used, considering the construct (brand trust) from the perspective of Numan (1998), which is based on both past successful experiences with the brand and on the belief in quality and future expectations regardless of history.

In summary, we aimed to assess (1) whether brand confidence and TRI 2.0 influence the WTU autonomous cars (2) to identify the relevance of brand trust and the TRI 2.0 in the WTU autonomous cars, (3) to evaluate how traditional automakers and information technology companies (ITCs) are evaluated in terms of brand trust and WTU AVs, and (4) to identify which brands have a better rating in terms of trust and in the willingness to use their AVs.

Regarding theoretical contributions, this study brings the discussion about brand trust as a moderator for innovation adoption. From the methodological point of view, the TRI 2.0 and Multidimensional Brand Trust Scale are applied in the Brazilian context as no previous studies were found for either model, combined or independently, neither on country or language (Portuguese) levels; while the management contribution involves addressing potential AV consumers' main concerns, allowing managers to highlight product development (or adaptation to the local market) and communication priority challenges.

This article, in its theoretical framework, briefly introduces AV technology and discusses the construct WTU to then explore the Technology Readiness Index in its version 2.0 and, finally, the role of brand trust. Following are the methodological procedures and results, as well as final considerations containing limitations and possibilities for future studies.

\section{THEORETICAL FRAMEWORK}

It can be argued that AVs can be seen as an incremental innovation to the traditional automotive industry, having the basic concept (automobile) reinforced by continuous improvements in the search for improvement (Santa Rita, de Araujo, de Paula, Oliveira Lima and Viana, 2010) or as a radical innovation (Engel, Blackwell and Miniardi, 2000), reconfiguring itself as a totally new product that significantly changes consumer behaviour models. As Rodrigues (2018b) shows, the potential migration from a property model to a usage model - especially on the instrumental use - and the reconfiguration of the relationship between consumers and their cars would bring it closer to the second (disruptive) than the first (incremental).

Also, the absence of past experiences that would allow a comparative analysis in order to establish a trust level in companies that are not originally from the auto industry could compromise the past reference to building brand trust (Gurviez and Korchia, 2003; Numan, 1998) as a response to potential questions (ethical, safety and privacy issues, for example) about decision-making models to be adopted in future AVs (Greene, 2016).

An "autonomous vehicle" (AV) can be understood as a passenger or goods transportation machine with a computer control system that integrates a set of sensors and actuators to accomplish a mission (take its cargo from point A to point B) in an autonomous and secure way (Ozguner, Stiller and Redmill, 2007, Gonçalves, 2011, Bunghez, 2015, Yağdereli, Gemci and Aktaş, 2015). In a high-level 
autonomous vehicle (level 5 at Society of Automotive Engineers - SAE - scale), it is expected that its user will only enter the destination or route and will not need to take control of this vehicle at any time (Mladenovic, Abbas and McPherson, 2014). In essence, an AV can be defined as "a vehicle that can perceive the environment, decide the route to the destination, and drive completely without any human assistance" (Bunghez, 2015, page 447).

In general, the benefits linked to AV adoption, such as accident reduction and/or traffic and parking optimization, are expected to outweigh uncertainty about ethical issues (Rodrigues, 2018a) or other consequences of its adoption (redesign of road systems, legal and liability discussions, increase in telecommunication flow, among others).

\subsection{Willingness to Use}

The use of willingness to use as the dependent variable is more applicable than willingness to pay or willingness to buy in this study not only because the technology is unavailable to the general public but also because of the fact that a consumption model was not the focus (purchased product vs. ondemand service) nor was monetary evaluation and judgement because it's not possible, at this time, to set the pricing impact (neither in proprietary or on-demand service modes). Thus, willingness to use is considered here as the positive propensity to use certain innovation, technology, or tool by understanding or projecting its capabilities and limitations.

Complementing the point above, it is considered that the popularization of AVs may imply a reduction of $43 \%$ in private vehicle ownership, decreasing the number of vehicles per family from 2.1 to 1.2 (Sivak and Schoettle, 2015) and thus justifying the approach on the use of such technology to the detriment of purchase/buy.

At this study, willingness to use considers the effective desire and possibility of technology consumption, considering its projected benefits and potential risks, because experimentation is nonexistent. It diverges from the intention of use, defined by Norman (1984, p. 365) because "the internal, mental characterization of the desired goal", as the necessary steps for the end activity (usage of Avs) are not clear and the technology is currently unavailable for consumers. As such, it is not possible to set the "internal specification of action responsible for the initiation and guidance of the resulting activity”, Norman (1984, p. 365).

According to Giffi and Vitale (2017), the perception about brand trust - the unique and abstract significance associated with brands from particular configurations of product characteristics and the firms' efforts to create meaning for these benefits (Park, Milberg and Lawson, 1991) - impacts the openness to experimentation with fully autonomous vehicles, presenting variations according to the origin of the respondent.

Despite the increasing number of projects from multiple AV-oriented companies, in general, consumers have no clear understanding about AV capabilities (Abraham, Lee, Brady, Fitzgerald, Mehler, Reimer, and Coughlin, 2016). The process of popularizing these products will be a considerable challenge both from the point of view of public knowledge about their operation $55 \%$ of 3,641 respondents in the UK (PWC, 2016) are aware of CAVs - and also from a technical perspective, especially considering the co-existence between Avs and non-autonomous vehicles (Gao, Hensley and Zielke, 2014).

\subsection{Innovation Adoption and Diffusion Models}

Two uncertainties permeate the introduction of new technologies and constitute the great challenge for managers and marketers in designing their marketing mix: whether and when the consumer market will adopt them (Morwitz, Steckel and Gupta, 2007).

Avs are closer to a radical or disruptive innovation with the potential to impact several aspects of the transportation ecosystem including safety on the road system environment, travel planning, and energy efficiency (Fagnant and Kockelman, 2015). The entry of large IT companies in this industry such as Google and Apple, for example, pictures new categories of products being introduced 
through innovation brought by new entrants, in this case, by creating technological skills that merge electronic products and mobility services (Schulze, MacDuffie and Taübe, 2015). Thus, initially we see new entrants and consolidated companies of one sector as competitors in adjacent markets and later, potentially, directly in the same market.

There are several models that explore the adoption and diffusion of innovations such as the Technology Acceptance Model (TAM), the Unified Theory of Acceptance and Use of Technology (UTAUT), and the Diffusion of Innovations (DOI), among others. The reason for choosing the Technology Readiness Index as the driver for the WTU comes from the fact that this model focuses on individual traits - to the detriment of the innovative thing per se - and thus, it is able to be extrapolated to products whose experimentation is non-existent or very low, such as the AVs.

The TRI model has already been applied in several contexts (Santa Rita et al., 2010). This is another reason why we chose to use it as the basis of the relational model of this study. This model, in its original version with 36 items in the scale, was validated for Brazil by Souza (2002). However, no validation was found for Brazil or in Portuguese for its updated version (2.0, with 16 items). So, the scale in version 2.0 had its internal consistency verified.

\subsection{Technology Readiness Index (TRI 2.0)}

The Technology Readiness Index (TRI) is a scale developed by Parasuraman (2000) and Parasuraman and Colby (2001) and updated by Parasuraman and Colby (2015) that identifies the propensity to adopt and use new technologies in order to fulfill goals in personal life (Meng, Elliot and Hall, 2010; Durán-García and Payan, 2016). It is based on drivers (adoption motivators) and mental inhibitors (barriers to adoption) that are related to the four independent dimensions that compose it (Souza and Luce, 2005; Santa Rita et al., 2010).

The formulation of these drivers and inhibitors considers eight paradoxes formulated by Mick and Fournier (1998) on people's reaction to technology (Duran-García and Payan, 2016; Pires and Alves da Costa Filho, 2008): (1) Control / Chaos (2) Freedom / Slavery, (3) New / Obsolete, (4) Competent / Incompetent, (5) Efficient / Inefficient, (6) Complete / Creates Needs, (7) Assimilation / Isolation and (8) Engaging / Disengaging.

The analysis of these eight paradoxes positions individuals in a continuous line where one end represents an active propensity for new technology and, in another, negative feelings that impede their consideration (Duran-García and Payan, 2016). The driving elements which favour adoption, named contributors, include the dimensions of optimism (positive views about technology and the possibility of greater control), flexibility, efficiency (thanks to it), and innovativeness, which is a tendency for a person to be a pioneer in adopting a new technology or to be an opinion leader. On the other hand, inhibitory elements (inhibitors) involve the discomfort - perception of lack of control and feeling of oppression towards technology - and insecurity - distrust and scepticism about technology and the ability to use it properly. The combination of TRI inhibitors and contributors indicates an individual's propensity to adopt new technologies.

It is relevant at this time to differentiate technology acceptance and technology readiness. In the first, there is a voluntary intention to use the technology followed by its effective adoption and use. It has cognitive constructs (perceived utility and perceived ease of use) as antecedents of one's attitude towards adoption of the technology, as presented by the Technology Acceptance Model - TAM (Davis, 1985). Technology readiness is the combination of technology-related beliefs and feelings that together determine a person's general predisposition for adopting technology products and services, per Parasuraman's (2000) explanation. Among the differences lies the fact that readiness encompasses not only cognitive criteria but also emotional attributes from the consumers (Duran-Garcia and Payán, 2016). Concomitantly, the unavailability of the object of study to the general public at the time of this study requires an approach that takes into account the non-practical knowledge of the object; this is another reason for the predilection for the TRI model. 
The model has been used consistently among different cultures. This is a positive factor because studies show that the predisposition to accept new technologies is influenced by cultural values (Rose and Straub, 1998). The Technology Readiness (TR) index varies among individuals and also is the result of different beliefs and of seeking to predict and explain the technology adoption and use percentage (Santa Rita et al., 2010). The 16 items are distributed in the same four dimensions according to Table 1 .

Finally, it is worth mentioning that the perceived risk construct, which is generally linked to the adoption of innovation models and to trust, is covered by seminal works like Jacoby and Kaplan (1972), Taylor (1974) and Cunningham (1967) and is incorporated by TRI in its discomfort dimension and not insecurity. The latter is more focused on the absence or weakness of information on the use of technology as well as on the individual's ability to use it. Souza and Luce (2005) opened their analysis about discomfort with the constraint (equivalent to social risk) and discomfort with functional and physical risk (Pires and Alves da Costa Filho, 2008). To keep integrity to the original model, it was decided to use the four original dimensions: optimism, innovation, discomfort, and insecurity.

Thus, with TRI 2.0 as a tool for measuring individual readiness for technology within the scope of this study, the following was considered as the first hypothesis:

H1: Individuals with higher scores on the TRI 2.0 scale have a greater willingness to use autonomous cars.

\subsection{Brand Trust}

Trust is a prime factor in human, business, and consumer relations and an essential survival mechanism in today's society. The lack of trust in everyday issues would make the functioning of these relations, and therefore of society, impossible. Trust is also an essential part of the human cognitive process, simplifying day-to-day life by simplifying decision-making processes. By trusting in something or someone, an individual's cognitive system is released and responsibility for the functioning or fulfilment of one's expectation is passed on to the other or to the thing in which one is trusted.

For the purposes of simplification, the trust construct will be considered from Luhmann's perspective as a "way of reducing the sense of complexity, uncertainty and perceived risk" $(1979$, as quoted in Numan, 1998), having in mind the difference presented by Numan (1998) between brand trust and brand confidence in which the second is based on "definite evidence or logical operations on definite evidence" while the first "is based on partial evidence". Per Numan's (1998) definition, "Trust is a mental action. This action is an expectation which person A has of an actor B that this actor B will act positively towards the goals which the trusting person A has. In this, the actor B, who has to be trusted, has the freedom to harm the trusting person A. The expectation is based on incomplete evidence".

The expectation linked to confidence, in turn, is based on direct evidence or logical conclusions from clear evidence. Thus, trust permeates the uncertainty about future results and builds confidence when it becomes the positive expectation and takes into account past events or the feeling that new expectations will be met which is derived from the safety and reliability of past similar capabilities.

As the object of this study (AVs) are not even available for experimentation and public opinion is built based on media vehicles and general media, trust would be more applicable than confidence. Nevertheless, brands used at this study do have products available on the market and the consumers may (or may not) have experienced them, which would approximate their evaluation to brand confidence.

However, in the Portuguese language - in which this study was conducted - both levels trust and confidence considered by Numan (1998) are translated the same way ("confiança"), not differentiating if this "confiança" is based on a solid evidence or on an expectation / projection. Hence, what's being called brand trust in this study focused on AVs is actually a combination of past references (which create confidence) in the case of traditional car manufacturers and incomplete projections (which 
Table 1. Technology readiness index 2.0 scale items; original copy and translated to Brazilian-portuguese (Parasuraman \& Colby, 2015; authors)

\begin{tabular}{|c|c|c|c|}
\hline ID & Dimension & Original (English) & Translated Item \\
\hline OPT1 & Optimism & $\begin{array}{l}\text { New technologies contribute to a better } \\
\text { quality of life }\end{array}$ & $\begin{array}{l}\text { As novas tecnologias contribuem para uma melhor } \\
\text { qualidade de vida. }\end{array}$ \\
\hline INN1 & Innovativeness & $\begin{array}{l}\text { Other people come to me for advice on } \\
\text { new technologies }\end{array}$ & $\begin{array}{l}\text { Outras pessoas me chamam para pedir conselhos } \\
\text { sobre novas tecnologias. }\end{array}$ \\
\hline DIS1 & Discomfort & $\begin{array}{l}\text { When I get technical support from a } \\
\text { provider of a high-tech product or service, } \\
\text { I sometimes feel as if I am being taken } \\
\text { advantage of by someone who knows more } \\
\text { than I do }\end{array}$ & $\begin{array}{l}\text { Quando recebo suporte técnico para um produto } \\
\text { ou serviço de alta tecnologia de um provedor, há } \\
\text { situações que sinto que alguém que sabe mais do } \\
\text { que eu está tirando proveito de mim. }\end{array}$ \\
\hline INS1 & Insecurity & $\begin{array}{l}\text { People are too dependent on technology to } \\
\text { do things for them }\end{array}$ & $\begin{array}{l}\text { As pessoas são muito dependentes da tecnologia } \\
\text { para fazer as coisas por elas. }\end{array}$ \\
\hline OPT2 & Optimism & $\begin{array}{l}\text { Technology gives me more freedom of } \\
\text { mobility }\end{array}$ & A tecnologia me dá mais liberdade de movimento. \\
\hline INN2 & Innovativeness & $\begin{array}{l}\text { Other people come to me for advice on } \\
\text { new technologies }\end{array}$ & $\begin{array}{l}\text { Geralmente, estou entre os primeiros do meu círculo } \\
\text { de amigos a adquirir uma nova tecnologia quando } \\
\text { ela surge. }\end{array}$ \\
\hline DIS2 & Discomfort & $\begin{array}{l}\text { Technical support lines are not helpful } \\
\text { because they don't explain things in terms } \\
\text { I understand }\end{array}$ & $\begin{array}{l}\text { As ligações de suporte técnico não são úteis porque } \\
\text { não explicam as coisas em termos que eu possa } \\
\text { entender. }\end{array}$ \\
\hline INS2 & Insecurity & $\begin{array}{l}\text { Too much technology distracts people to a } \\
\text { point that is harmful }\end{array}$ & $\begin{array}{l}\text { Muita tecnologia distrai as pessoas ao ponto de ser } \\
\text { prejudicial. }\end{array}$ \\
\hline OPT3 & Optimism & $\begin{array}{l}\text { Technology gives people more control over } \\
\text { their daily lives }\end{array}$ & $\begin{array}{l}\text { A tecnologia dá às pessoas mais controle sobre sua } \\
\text { vida diária. }\end{array}$ \\
\hline INN3 & Innovativeness & $\begin{array}{l}\text { I can usually figure out new high-tech } \\
\text { products and services without help from } \\
\text { others }\end{array}$ & $\begin{array}{l}\text { Normalmente posso aprender a usar produtos e } \\
\text { serviços de alta tecnologia sem a ajuda de outras } \\
\text { pessoas. }\end{array}$ \\
\hline DIS3 & Discomfort & $\begin{array}{l}\text { Sometimes, I think that technology systems } \\
\text { are not designed for use by ordinary people }\end{array}$ & $\begin{array}{l}\text { Às vezes penso que os sistemas de tecnologia não } \\
\text { foram planejados para serem usados por pessoas } \\
\text { comuns. }\end{array}$ \\
\hline INS3 & Insecurity & $\begin{array}{l}\text { Technology lowers the quality of } \\
\text { relationships by reducing personal } \\
\text { interaction }\end{array}$ & $\begin{array}{l}\text { A tecnologia diminui a qualidade dos } \\
\text { relacionamentos humanos ao reduzir a interação } \\
\text { pessoal. }\end{array}$ \\
\hline OPT4 & Optimism & $\begin{array}{l}\text { Technology makes me more productive in } \\
\text { my personal life }\end{array}$ & $\begin{array}{l}\text { A tecnologia aumenta a produtividade em minha } \\
\text { vida pessoal. }\end{array}$ \\
\hline INN4 & Innovativeness & $\begin{array}{l}\text { I keep up with the latest technological } \\
\text { developments in my areas of interest }\end{array}$ & $\begin{array}{l}\text { Me mantenho atualizado sobre os desenvolvimentos } \\
\text { tecnológicos mais recentes nas minhas áreas de } \\
\text { interesse. }\end{array}$ \\
\hline DIS4 & Discomfort & $\begin{array}{l}\text { There is no such thing as a manual for a } \\
\text { high-tech product or service that's written } \\
\text { in plain language }\end{array}$ & $\begin{array}{l}\text { Não existe um manual para um produto ou serviço } \\
\text { de alta tecnologia que esteja escrito em uma } \\
\text { linguagem fácil de entender. }\end{array}$ \\
\hline INS4 & Insecurity & $\begin{array}{l}\text { I do not feel confident doing business with } \\
\text { a place that can only be reached online }\end{array}$ & $\begin{array}{l}\text { Não me sinto seguro fazendo negócios com uma } \\
\text { empresa que pode ser contatada apenas "online". }\end{array}$ \\
\hline
\end{tabular}

create trust) in the case of ICTs and new entrants to the automotive market. New specific entrants (i.e. brands created specifically for $\mathrm{AVs}$ ), not having past references, would theoretically be at a disadvantage in both interpretations of the term trust in Brazilian Portuguese.

The distrust of AV technology, according to Vallet (2013), would be linked to the perception that the artificial intelligence in charge of the AVs would not have the same decision quality as humans. It also states that, among the public consulted, traditional automakers such as Honda, Ford, or Toyota would have a preference for using technology companies. 
For this study, the operationalization of the brand trust construct was done through the Multidimensional Brand Trust Scale formulated by Gurviez and Korchia (2003), which, through an eight-item scale, considers trust under three dimensions: (1) credibility, (2) integrity, and (3) benevolence. Its validation demonstrated a strong relationship between trust and consumption commitment.

In this context, the credibility attributed to a brand comes from its capacity to reach the expected levels of performance (as the authors state, "meet the technical expectations of consumers") (Gurviez and Korchia, 2003, p. 5), or the brand is capable of satisfying consumer's product / service functional expectations. Integrity reflects the respect and honesty of a brand's claims against what is delivered to the consumer. Benevolence considers a long-term relationship with consumer interests, supplanting a brand interest in the short term, allowing the consumer to envision a future safety perception in a lasting relationship with the brand.

Taking Numan's (1998) trust construct (based on extrapolation) - and the Multidimensional Brand Trust Scale of Gurviez and Korchia (2003), it is hypothesized that:

H2: Greater trust in the brand will positively influence the WTU AVs of that brand.

How (or how much) brand trust and the TRI mutually impact the willingness to use new technologies has not been found in the literature either in general or for AVs in particular.

\section{METHODOLOGICAL PROCEDURES}

The research approach was quantitative, using a survey technique. The brand trust construct was measured using the Gurviez and Korchia (2003) Multidimensional Brand Trust Scale.

As for TRI, the "combination of positive and negative feelings about technology underlies the domain of technology readiness" (Parasuraman, 2000, p. 309); thus, it determines a general predisposition of an individual to adopt technology products and services.

The relationship between the variables and their dimensions can be seen in Figure 1.

In addition, WTU as a dependent variable took into consideration previous studies by Hyde, Dalton and Stevens (2017), Kyriakidis, Happee and Winter (2015), Choi and Ji (2015), Giffi and Vitale (2017) and Giffi, Vitale, Schiller and Robinson (2018), who evaluated the willingness to use AVs. The brand component was added which resulted in two approaches for this study: (1)

Figure 1. Relational model (authors)

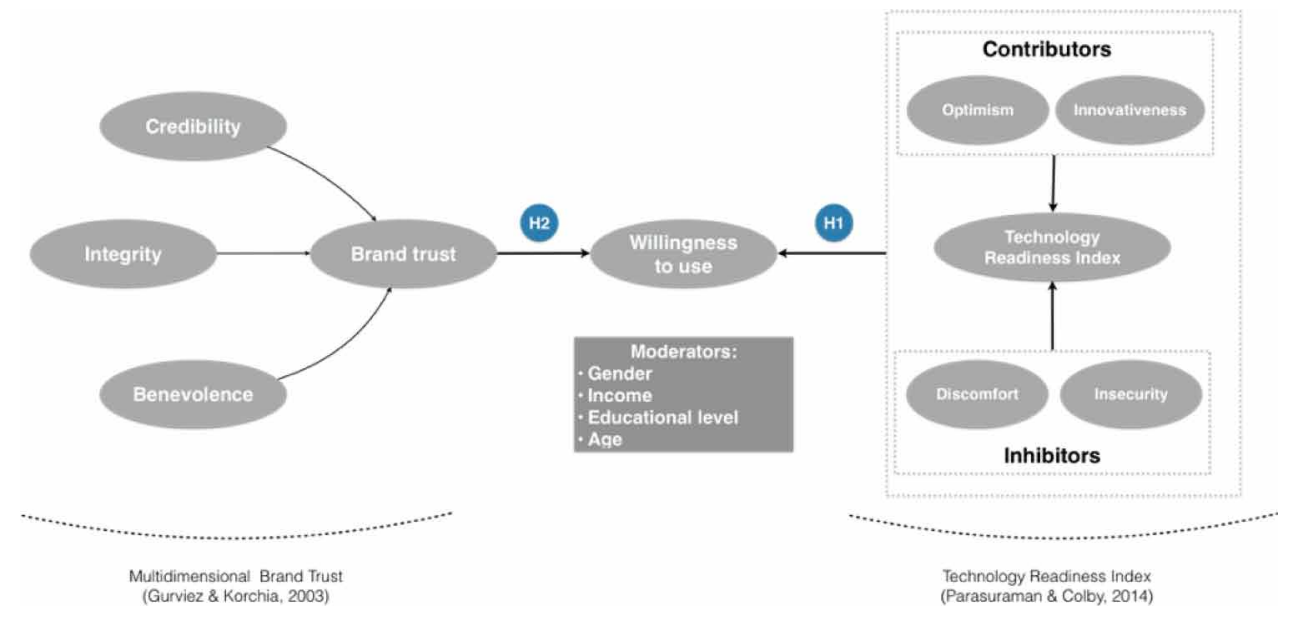


General WTU AVs is based on a one-dimensional and specific item and (2) WTU per brand, from one-dimensional and specific item for each of the 11 brands used in the study. WTU is considered at this study, per Daziano, Sarrias and Leard (2017), as a representation of a level of interest of the individual towards the object.

\subsection{Sample}

The survey used a convenient non-probabilistic sample, men and women users of individual transport (own car, taxi, Uber, Cabify, etc.). A total of 213 valid and complete participations were obtained (n $=213), 90$ males $(42.45 \%), 122$ females $(57.22 \%)$ and $1(0.33 \%)$ with undeclared gender.

Responses were achieved through a snowball technique, sponsored ads on Facebook and Google, as well as printed questionnaires (later digitized) in events and lectures.

\subsection{Method and Data Collection Instrument}

The survey was carried out using the QuestionPro online tool and printed questionnaires that were delivered and collected by the researchers soon after their completion; the answers were later inserted in the online tool to facilitate data extraction. The constructs were operationalized through validated scales and previous studies and levelled using a five-point Likert scale which is recommended due to ease of construction by the researcher and understanding by the respondent.

A backtranslation procedure was adopted. The translation of the items from English into Brazilian Portuguese was performed by a Brazilian Portuguese native speaker and English teacher. When completed, the text was sent to another Brazilian native translation professional with a high degree of English proficiency for reverse translation purposes, presenting necessary consistency.

The willingness to use AVs was considered under two prisms: "general WTU" and "WTU by brand", considering the 11 brands involved. These variables were interpreted in a one-dimensional manner. The brands used in the questionnaire were obtained by crossing those known to be involved in the development of AVs (CB INSIGHTS, 2017) with reports indicating more reliable car brands and the 20 largest ITCs (Information Technology Companies) in terms of revenue, according to the Fortune 500 magazine (FORTUNE, 2017). They were validated through consultation with potential consumers, resulting in the 11 brands that were part of this study: Chevrolet (as GM / General Motors brand is known and advertised in Brazil), Volkswagen, Ford, Toyota, Fiat, Tesla Motors, Apple, Samsung, Microsoft, Google, and Uber.

Other scales used for brand trust and the Technology Readiness Index itself were checked for their consistency from the total number of respondents $(n=213)$.

The internal consistency of the Technology Readiness Index scale was checked by considering the responses of each individual to the 16 items that compose it. Based on these data, the TRI 2.0 presented a satisfactory degree of reliability (Cronbach's alpha $=0.769$ ). Regarding the Multidimensional Brand Trust Scale, each individual evaluated such construct for the 11 brands in the survey. In order to assess the internal consistency in its eight items and three dimensions, the average value was used for each item by individual. The obtained Cronbach's alpha in the sample $(n=213)$ showed a high degree of reliability (Cronbach's alpha $=0.914)$.

\section{DESCRIPTION, INTERPRETATION AND DATA ANALYSIS}

In this study, AV nomenclature was used to designate individual or low cargo transport (up to 8 passengers) terrestrial autonomous vehicles. They were chosen as a cut-off of the object of study according to the understanding of the term "car" adopted by CTB - Brazilian Traffic Code (Código de Trânsito Brasileiro), not distinguishing, however, whether its use will be proprietary (purchase of an AV) or as an on-demand service. In addition, only high automation or full automation AVs, identified at levels 4 and 5 according to SAE (Society of Automotive Engineers), were considered. This is the level where the vehicle is roughly capable of driving itself without any expected interference 
Table 2. Multiple linear regression coefficients confronting the response variable - willingness to use / WTU - with predictor variables - TRI, age, educational level, income and gender (authors)

\begin{tabular}{|l|l|l|l|l|l|}
\hline \multicolumn{1}{|c|}{ Variable } & \multicolumn{1}{c|}{ Coefficients } & \multicolumn{1}{c|}{ Std. Error } & \multicolumn{1}{c|}{ t } & \multicolumn{1}{c|}{ P-Value } & \multicolumn{1}{c|}{ VIF } \\
\hline (Constant) & 1,746 & 0,604 & 2,89 & 0,004 & \\
\hline TRI & 0,545 & 0,117 & 4,65 & 0,000 & 1,07 \\
\hline Age & $-0,017$ & 0,008 & $-2,16$ & 0,032 & 1,49 \\
\hline Educational level (educ) & 0,0490 & 0,099 & 0,49 & 0,623 & 1,09 \\
\hline Income & 0,120 & 0,071 & 1,69 & 0,093 & 1,55 \\
\hline Gender & 0,503 & 0,115 & 4,37 & 0,000 & 1,05 \\
\hline
\end{tabular}

of a human driver (Kyriakidis et al., 2015, Smith, 2013), nor is it teleoperated / remote controlled (Frazzoli, Dahlen and Feron, 2002).

The obtained data were previously treated, eliminating missing values and outliers, reaching the sample of 213 valid respondents $(n=213)$. The analysis of these respondents sustained $\mathrm{H} 1$ and $\mathrm{H} 2$.

The hypothesis H1 (individuals with higher scores in the TRI 2.0 scale shows a greater WTU autonomous cars) is supported as the linear correlation coefficient between TRI and AV provision is positive and equal to 0.357 ( $\mathrm{p}<0.001$ ). In a linear regression model in which AVs WTU is explained by TRI, age, educational level, income and gender, the TRI coefficient is positive and significant ( $\beta$ $=0.545, \mathrm{p}<0.001)$.

At the significance level of 5\%, it was possible to identify two significant predictors: (i) as the TRI increases, the use of autonomous cars also increases (sustaining H1); and ii) in a complementary manner, there was a valid influence of gender in this relation. Men, compared to women (and keeping the other variables constant), are more willing to use AVs. This is in line with results obtained in previous studies by Becker and Axhausen (2016) and Kyriakidis et al. (2015). Tables 2 and 3 present the output of the multiple linear regression model in which the response variable (willingness to use, WTU) is compared with the predictive variables TRI, age, educational level, income and gender.

$\mathrm{H} 2$ hypothesis (higher brand trust will positively influence AV WTU of the same brand) is also supported by identifying that there is a strong relationship between those variables (brand trust and WTU AVs of the same brand).

Answers were grouped considering the three brands whose respondents showed the highest brand trust and the three brands that presented the least brand trust to measure the average WTU. It was found that the greater the brand trust, the greater the WTU. The average WTU among the high trusted brands was 4.15 , versus the average of 3.15 for the brands with lower trust $(t=11.1, p<0.001)$.

In addition, 11 multiple linear regression models were performed in order to portray the impact of TRI and brand trust for each of the brands used in the study. Considering the WTU of each brand as the response variable and brand trust, TRI, age, education level, income and gender as predictor variables, it was possible to observe that brand trust was significant for all 11 brands, while TRI was significant only for the Tesla brand (p-value equal to 0.007), as presented in Table 3. It's presumed that, since Tesla vehicles are not available in Brazil and, consequently, brand trust is potentially tied to brand image, respondents took this individual perception as the reference to evaluate it. It is worth mentioning that the Tesla brand is the one most mentioned as "not known" among respondents (26 out of 213 valid responses).

Taking into consideration Brand trust and WTU by type of company (traditional car manufacturers and ITCs), once grouped, brands Apple, Google, Toyota, Samsung and Microsoft achieved, respectively, the top five positions in terms of brand trust, while Tesla Motors, Toyota, Apple, Google, and Volkswagen, respectively, the top five positions in terms of WTU AVs, as shown in Tables 4, 5 and 6. 
Table 3. Multiple linear regression selected statistics

\begin{tabular}{|c|c|c|c|c|c|c|c|c|}
\hline & \multicolumn{2}{|c|}{ GM } & \multicolumn{2}{|c|}{ TOYOTA } & \multicolumn{2}{|c|}{ FORD } & \multicolumn{2}{|c|}{ VOLKSWAGEN } \\
\hline & Coeff. & P-Value & Coeff. & P-Value & Coeff. & P-Value & Coeff. & P-Value \\
\hline (Constant) & 1,69 & 0,023 & 1,85 & 0,011 & 1,55 & 0,039 & 0,71 & 0,355 \\
\hline Brand Trust & 0,69 & 0,000 & 0,50 & 0,000 & 0,68 & 0,000 & 0,80 & 0,000 \\
\hline TRI & 0,20 & 0,149 & 0,14 & 0,290 & 0,20 & 0,146 & 0,15 & 0,279 \\
\hline Age & $-0,01$ & 0,369 & 0,01 & 0,560 & $-0,02$ & 0,069 & 0,00 & 0,900 \\
\hline $\begin{array}{l}\text { Educational } \\
\text { level }\end{array}$ & $-0,26$ & 0,023 & $-0,09$ & 0,424 & $-0,20$ & 0,083 & $-0,11$ & 0,326 \\
\hline Income & 0,08 & 0,305 & 0,00 & 0,959 & 0,11 & 0,188 & $-0,01$ & 0,892 \\
\hline Gender & 0,12 & 0,364 & 0,07 & 0,557 & 0,20 & 0,128 & 0,14 & 0,284 \\
\hline $\mathrm{R}^{2}$ & \multicolumn{2}{|l|}{$28,23 \%$} & \multicolumn{2}{|l|}{$15,88 \%$} & \multicolumn{2}{|l|}{$24,94 \%$} & \multicolumn{2}{|l|}{$31,44 \%$} \\
\hline \multirow[t]{3}{*}{ Adjusted $\mathrm{R}^{2}$} & \multicolumn{2}{|l|}{$26,13 \%$} & \multicolumn{2}{|l|}{$13,42 \%$} & \multicolumn{2}{|l|}{$22,75 \%$} & \multicolumn{2}{|l|}{$29,43 \%$} \\
\hline & \multicolumn{2}{|c|}{ FIAT } & \multicolumn{2}{|c|}{ TESLA } & \multicolumn{2}{|c|}{ APPLE } & \multicolumn{2}{|c|}{ SAMSUNG } \\
\hline & Coeff. & P-Value & Coeff. & P-Value & Coeff. & P-Value & Coeff. & P-Value \\
\hline Constant & 0,32 & 0,688 & 0,04 & 0,953 & 0,88 & 0,296 & 0,19 & 0,820 \\
\hline Brand trust & 0,79 & 0,000 & 0,91 & 0,000 & 0,61 & 0,000 & 0,87 & 0,000 \\
\hline TRI & 0,16 & 0,278 & 0,39 & 0,007 & 0,26 & 0,082 & 0,03 & 0,844 \\
\hline Age & $-0,01$ & 0,499 & $-0,01$ & 0,453 & $-0,01$ & 0,394 & $-0,01$ & 0,443 \\
\hline $\begin{array}{l}\text { Educational } \\
\text { level }\end{array}$ & $-0,04$ & 0,721 & $-0,07$ & 0,557 & $-0,06$ & 0,605 & $-0,05$ & 0,657 \\
\hline Income & 0,04 & 0,626 & 0,02 & 0,842 & 0,05 & 0,554 & 0,12 & 0,174 \\
\hline Gender & 0,09 & 0,532 & $-0,13$ & 0,324 & 0,27 & 0,050 & 0,27 & 0,058 \\
\hline $\mathrm{R}^{2}$ & \multicolumn{2}{|l|}{$30,63 \%$} & \multicolumn{2}{|l|}{$44,19 \%$} & \multicolumn{2}{|l|}{$18,54 \%$} & \multicolumn{2}{|l|}{$31,20 \%$} \\
\hline \multirow[t]{3}{*}{ Adjusted $\mathrm{R}^{2}$} & \multicolumn{2}{|c|}{$28,60 \%$} & \multicolumn{2}{|c|}{$42,25 \%$} & \multicolumn{2}{|l|}{$16,12 \%$} & \multicolumn{2}{|l|}{$29,19 \%$} \\
\hline & \multicolumn{2}{|c|}{ MICROSOFT } & \multicolumn{2}{|c|}{ GOOGLE } & & BER & & \\
\hline & Coeff. & P-Value & Coeff. & P-Value & Coeff. & P-Value & & \\
\hline Constant & 1,36 & 0,138 & 1,29 & 0,133 & 0,28 & 0,714 & & \\
\hline Brand trust & 0,75 & 0,000 & 0,53 & 0,000 & 0,75 & 0,000 & & \\
\hline TRI & 0,05 & 0,764 & 0,29 & 0,054 & 0,22 & 0,127 & & \\
\hline Age & $-0,02$ & 0,142 & $-0,01$ & 0,165 & $-0,01$ & 0,763 & & \\
\hline $\begin{array}{l}\text { Educational } \\
\text { level }\end{array}$ & $-0,19$ & 0,157 & $-0,05$ & 0,685 & $-0,07$ & 0,538 & & \\
\hline Income & 0,13 & 0,190 & 0,04 & 0,659 & $-0,02$ & 0,828 & & \\
\hline Gender & 0,27 & 0,077 & 0,23 & 0,099 & 0,39 & 0,006 & & \\
\hline $\mathrm{R}^{2}$ & $26,26 \%$ & & $16,32 \%$ & & $32,47 \%$ & & & \\
\hline Adjusted $\mathrm{R}^{2}$ & $24,11 \%$ & & $13,83 \%$ & & $30,47 \%$ & & & \\
\hline
\end{tabular}

Respondents show a band trust predilection for ITCs in detriment to car manufacturers (respectively 4.000 versus 3.682), nevertheless, higher WTU AVs were produced by car manufacturers than by ITCs (respectively 3.777 versus 3.747 ). 
Table 4. Brand trust and Willingness to use (WTU) average rating among ITCs (authors)

\begin{tabular}{|l|l|l|l|l|l|l|}
\hline & \multicolumn{1}{|c|}{ Apple } & \multicolumn{1}{c|}{ Samsung } & Microsoft & \multicolumn{1}{|c|}{ Google } & \multicolumn{1}{c|}{ Uber } & \multicolumn{1}{c|}{ ITCs } \\
\hline Average brand trust & 4,278 & 3,869 & 3,866 & 4,222 & 3,764 & 4,000 \\
\hline Average WTU & 4,090 & 3,601 & 3,488 & 4,033 & 3,524 & 3,747 \\
\hline
\end{tabular}

Table 5. Brand trust and Willingness to use (WTU) average rating among Automakers (authors)

\begin{tabular}{|l|l|l|l|l|l|l|l|}
\hline & $\begin{array}{c}\text { Chevrolet / } \\
\text { GM }\end{array}$ & \multicolumn{1}{|c|}{ Toyota } & Ford & Volkswagen & Fiat & Tesla & Automakers \\
\hline Average brand trust & 3,622 & 3,983 & 3,635 & 3,632 & 3,451 & 3,767 & 3,682 \\
\hline Average WTU & 3,646 & 4,123 & 3,596 & 3,656 & 3,319 & 4,322 & 3,777 \\
\hline
\end{tabular}

Table 6. Average brand trust and willingness to use brand's line-up (authors)

\begin{tabular}{|l|l|l|l|l|}
\hline Position & \multicolumn{2}{|c|}{ Average Brand Trust } & \multicolumn{2}{c|}{ Average WTU } \\
\hline 1 & Apple & 4,278 & Tesla & 4,322 \\
\hline 2 & Google & 4,222 & Toyota & 4,123 \\
\hline 3 & Toyota & 3,983 & Apple & 4,090 \\
\hline 4 & Samsung & 3,869 & Google & 4,033 \\
\hline 5 & Microsoft & 3,866 & Volkswagen & 3,656 \\
\hline 6 & Tesla & 3,767 & Chevrolet / GM & 3,646 \\
\hline 7 & Uber & 3,764 & Samsung & 3,601 \\
\hline 8 & Ford & 3,635 & Ford & 3,596 \\
\hline 9 & Volkswagen & 3,632 & Uber & 3,524 \\
\hline 10 & Chevrolet / GM & 3,622 & Microsoft & 3,488 \\
\hline 11 & Fiat & 3,451 & Fiat & 3,319 \\
\hline
\end{tabular}

\section{FINAL CONSIDERATIONS}

Automakers and information technology companies face a similar momentum as information systems in the 1980s: the battle between hardware and software. What is the relevance of each element in determining whom the customer belongs to? Concerned not to become only mechanized machine suppliers, automakers seek to accelerate their innovation process against disruptive technology, while ITCs foresee a new data source for personalizing their content and service offerings. Added to this is the discussion about the migration of a 'property' model to 'usage' (especially in utilitarian situations), thus amplifying the impact on mobility related industries (insurance, real estate, health, fuels) to understand the search for a sustainable business model in a century-old industry. Are the cars meant to become transport boxes (utilitarian approach) or adult toys (hedonistic approach)?

Apart from the object of this study and its potential approaches, although considering its peculiarities, it was considered here how an individual characteristic - technology readiness - would reflect the potential WTU of such technology and how previously built brand trust, by itself and combined with technology readiness, would affect this WTU. The TRI scale was chosen because it's one of the few models that measures individual characteristics independently of the innovation itself 
and would not depend on the individual's exposure to the technology to set their attitude (not counting on perceived ease of use, perceived usefulness or any other variable from other innovation models).

It's accepted that this study might have been impacted by other constructs that exist in the relationship between consumers and brands, such as brand image, brand equity, as well as theories about risk and perceived risk (Bauer, 1960). For this reason, we chose scales such as TRI, that incorporates the risk factor to a certain extent - general risk could be identified in the discomfort dimension and psychological risk in the insecurity dimension - and the Multidimensional Brand Trust Scale of Gurviez and Korchia (2003), which portrays both present and future trust.

Backed by Numan (1998), trust does not necessarily presuppose previous experience with the object of study (not coincidentally, the reason why TRI was chosen as a reference for technology readiness), allowing the extrapolation of past experiences with a brand for hypothetical situations, like such brand offering an AV. The trust construct sought to incorporate Bauer's (1960) physical risk factor, because this is the main concern about AVs documented in the literature according to Cavoli et al. (2017). So, the intent was to simplify the approach without needing to incorporate brand image models, although this may have impacted the perception about a specific brand (Tesla).

The objective was not only to replicate previous studies on technology acceptance - albeit with new scales - but to bring to the discussion of consumer behaviour its relationship with brands and how this impacts usage decisions. This variable - brand trust - was more relevant than technology readiness itself for 10 of 11 brands. Since Tesla Motors is the only brand that deviates from this scenario and, not by chance, it the only brand not available in the country, it is believed that brand trust was influenced by brand image rather that past experiences (confidence) or extrapolations from the perception in other scenarios (trust).

As AV technology comes closer to the general public, as well as more experienceable, perceptions should be added to empirical impressions which are initially favoured (or not) by the way the potential consumer will be willing to use the AV by brand "a" or " $b$ ".

\subsection{Contributions}

In addition to the demonstration of greater relevance of brand trust in comparison to the Technology Readiness Index 2.0 in WTU AVs, this study brings as theoretical contributions the discussion about the differentiation of the construct trust in the brand as a function of past experiences, treated by Numan (1998) as brand confidence, or the extrapolation between product lines or situations not directly similar to the object on which it is intended to measure, also put by Numan (1998) as a brand trust, for the Brazilian market, considering that both terms are equally translated into a common Portuguese word (“confiança”).

The management contributions involve, mainly with the literature review, addressing the main concerns of AV technology's potential consumers, allowing managers to identify the priority issues in the development (or adaptation to the local market) of the product and in its communication. The analysis of brand trust, in turn, also allows managers to know the individuals' perception about the brands used in the study and how they position themselves against each other.

\subsection{Limitations}

The study presents limitations related to the methods of respondents' selection and others identified during the execution of the research. It is worth mentioning initially that although it is a result of a consultation with potential consumers, only the brands selected for this study are taken into account and other brands and companies may present different results.

It should also be considered that the results represent the view of the sample (with 213 valid respondents) and their characteristics. Number os respondants were limited to the available timeframe to run the research as well as the result reflected valid respondants only after elimination of missing values and outliers. As such, any extrapolation must take this premise into account. 
Complementarily, the use of the snowball technique to obtain respondents tends to result in homogeneous groups, since this is one of the reasons for its use (Vinuto, 2014). In this way, the presented results cannot be extrapolated for the whole Brazilian population. This can be portrayed, for example, in the geographical division of respondents, with $71.36 \%$ located in the state of São Paulo.

A particular concern in regard to an incipient technology (AVs) was that there might be a misunderstanding or misconception about its nature and operation among general brazilian population, reason why, initially, snowball technique was chosen. Not being successful on getting enough valid and complete responses, particularly in a way that would allow a comparison among 11 tested brands, Facebook and Google ads were later used to increase respondants base during the limited time available to collect responses.

Despite the consistency validation of the Multidimensional Brand Trust Scale, considering Numan's (1998) different interpretations for trust and confidence in English language and the common term in Brazilian Portuguese ("confiança"), there might have been inconsistencies from having respondents assign their trust levels for some brands based on past experiences as solid evidences (confidence) and the extrapolation when such experiences were non-existent (trust). So, other elements such as brand image and brand equity may have influenced at the result.

\subsection{Recommendations for Future Studies}

Suggestions for future studies are a deepening of issues previously covered, empirically or theoretically, by other authors. Including, for example, the general attitude of the future AV consumers (in line with Hyde et al., 2017, Kyriakidis et al., 2015 and Lavieri, Garikapati, Bhat, Pendyala, Astroza and Dias, 2017), the application of other innovation adoption models (following Choi and Ji, 2015 and Adell, 2010) and specific benefits and challenges, such as the opinion and WTU of people with reduced mobility (elderly, people with disabilities, etc), similar to Litman (2014) and Harper, Hendrickson, Magones and Samaras (2016), communication between vehicles and pedestrians (Urmson, 2008), and the impact on the infrastructure and social dynamics of the road system with popularization of AV s (Perkola, 2017, Gomes, 2014, Muñoz and Al Naqvi, 2017, Eltoweissy, Olariu and Yunis, 2010).

In a similar way, there are opportunities to include brands as moderators for AVs (or any other technology) usage, including other variables that might impact not only a general WTU AVs but the influence of these variables for each specific brand. 


\section{REFERENCES}

Abraham, H., Lee, C., Brady, S., Fitzgerald, C., Mehler, B., Reimer, B., \& Coughlin, J. F. (2016). Autonomous vehicles, trust, and driving alternatives: A survey of consumer preferences. In Transportation Research Board 96th Annual Meeting (pp. 8-12). Academic Press.

Adell, E. (2010). Acceptance of driver support systems. In Proceedings of the European conference on human centred design for intelligent transport systems (Vol. 2, pp. 475-486). Humanist VCE.

Bauer, R. A. (1960). Consumer behavior as risk taking. In Proceedings of the 43rd National Conference of the American Marketing Assocation. American Marketing Association.

Becker, F., and Axhausen, K. W. (2016). Literature review on behavioral experiments for autonomous vehicles. Arbeitsberichte Verkehrs-und Raumplanung, 1179.

Burns, L. D., Jordan, W. C., \& Scarborough, B. A. (2013). Transforming personal mobility. The Earth Institute, 431,432 .

Bunghez, C. L. (2015). The Future of Transportation-Autonomous Vehicles. International Journal of Economic Practices and Theories, 5(5), 447-454.

Cavoli, C., Phillips, B., Cohen, T., \& Jones, P. (2017). Social and behavioural questions associated with Automated Vehicles A Literature Review. UCL Transport Institute January.

CB Insights. (2017). 44 Corporations Working On Autonomous Vehicles. https://www.cbinsights.com/blog/ autonomous-driverless-vehicles-corporations-list/

Choi, J. K., \& Ji, Y. G. (2015). Investigating the importance of trust on adopting an autonomous vehicle. International Journal of Human-Computer Interaction, 31(10), 692-702. doi:10.1080/10447318.2015.1070549

Cunningham, S. M. (1967). The major dimensions of perceived risk. In D. F. Cox (Ed.), Risk taking and information handling in consumer behavior. Harvard University Press.

Davis, F. D. (1985). A technology acceptance model for empirically testing new end-user information systems: Theory and results (Doctoral dissertation). Massachusetts Institute of Technology.

Daziano, R. A., Sarrias, M., \& Leard, B. (2017). Are consumers willing to pay to let cars drive for them? Analyzing response to autonomous vehicles. Transportation Research Part C, Emerging Technologies, 78, 150-164. doi:10.1016/j.trc.2017.03.003

Durán-García, D., \& Payan, R. (2016). Colombian consumer willingness to adopt innovative technology products and services. Dissertação de Mestrado, Colegio de Estudios Superiores de Administración -CESA, Bogotá, Colômbia.

Eltoweissy, M., Olariu, S., \& Younis, M. (2010, August). Towards autonomous vehicular clouds. In International Conference on Ad Hoc Networks (pp. 1-16). Springer.

Engel, J. F., Blackwell, R. D., \& Miniard, P. W. (2000). Comportamento do consumidor (8th ed.). LTC.

Fagnant, D. J., \& Kockelman, K. (2015). Preparing a nation for autonomous vehicles: Opportunities, barriers and policy recommendations. Transportation Research Part A, Policy and Practice, 77, 167-181. doi:10.1016/j. tra.2015.04.003

Fortune. (2017). Fortune Global 500. https://fortune.com/global500/list/filtered?sector=Technology

Frazzoli, E., Dahleh, M. A., \& Feron, E. (2002). Real-time motion planning for agile autonomous vehicles. Journal of Guidance, Control, and Dynamics, 25(1), 116-129. doi:10.2514/2.4856

Gao, P., Hensley, R., \& Zielke, A. (2014, Oct.). A road map to the future for the auto industry. McKinsey Quarterly.

Giffi, C. A., \& Vitale, J., Jr. (2017). What's ahead for fully autonomous driving: Consumer opinions on advanced vehicle Technology. Perspectives from Deloitte's Global Automotive Consumer Study. https://www2.deloitte. $\mathrm{com} /$ content/dam/Deloitte/cn/Documents/cip/deloitte-cn-cip-fully-auto-driving-2017-en-170814.pdf 
Giffi, C. A., Vitale, J. Jr, Schiller, T., \& Robinson, R. (2018). A reality check on advanced vehicle technologies. Insights exploring new automotive business models and consumer preferences. Deloitte Insights.

Gomes, L. (2014). Hidden obstacles for google's self-driving cars: Impressive progress hides major limitations of google's quest for automated driving. MIT Technol. Rev.

Gonçalves, L. F. S. (2011). Desenvolvimento de Navegação Autônoma por GNSS. 2011. 192f (Doctoral dissertation). Escola Politécnica da Universidade de São Paulo, Universidade de São Paulo, São Paulo.

Goodall, N. J. (2014). Ethical decision making during automated vehicle crashes. Transportation Research Record: Journal of the Transportation Research Board, 2424(1), 58-65. doi:10.3141/2424-07

Greene, J. D. (2016). Our driverless dilemma. Science, 352(6293), 1514-1515. doi:10.1126/science.aaf9534 PMID:27339966

Gurviez, P., \& Korchia, M. (2003). Proposal for a multidimensional brand trust scale. 32nd Emac-ConferenceGlasgow, Marketing: Responsible and Relevant, 438-452.

Harper, C. D., Hendrickson, C. T., Mangones, S., \& Samaras, C. (2016). Estimating potential increases in travel with autonomous vehicles for the non-driving, elderly and people with travel-restrictive medical conditions. Transportation Research Part C, Emerging Technologies, 72, 1-9. doi:10.1016/j.trc.2016.09.003

Hyde, S., Dalton, P., \& Stevens, A. (2017). Attitudes to Autonomous Vehicles (No. PPR823). Academic Press. Jacoby, J., \& Kaplan, L. B. (1972). The components of perceived risk. ACR Special Volumes.

Kyriakidis, M., Happee, R., \& Winter, J. C. (2015). Public opinion on automated driving: Results of an international questionnaire among 5000 respondents. Transportation Research Part F: Traffic Psychology and Behaviour, 32, 127-140. doi:10.1016/j.trf.2015.04.014

Lavieri, P. S., Garikapati, V. M., Bhat, C. R., Pendyala, R. M., Astroza, S., \& Dias, F. F. (2017). Modeling individual preferences for ownership and sharing of autonomous vehicle technologies. Transportation Research Record: Journal of the Transportation Research Board, 2665(1), 1-10. doi:10.3141/2665-01

Litman, T. (2017). Autonomous vehicle implementation predictions. Victoria Transport Policy Institute.

Meng, J., Elliott, K. M., \& Hall, M. C. (2009). Technology readiness index (TRI): Assessing cross-cultural validity. Journal of International Consumer Marketing, 22(1), 19-31. doi:10.1080/08961530902844915

Mick, D. G., \& Fournier, S. (1998). Paradoxes of technology: Consumer cognizance, emotions, and coping strategies. The Journal of Consumer Research, 25(2), 123-143. doi:10.1086/209531

Mladenović, M. N., Abbas, M., \& McPherson, T. (2014, May). Development of socially sustainable traffic-control principles for self-driving vehicles: The ethics of anthropocentric design. In Proceedings of the IEEE 2014 International Symposium on Ethics in Engineering, Science, and Technology (p. 77). IEEE Press. doi:10.1109/ ETHICS.2014.6893448

Morwitz, V. G., Steckel, J. H., \& Gupta, A. (2007). When do purchase intentions predict sales? International Journal of Forecasting, 23(3), 347-364. doi:10.1016/j.ijforecast.2007.05.015

Muñoz, J. M., \& Naqvi, A. (2017). Artificial Intelligence and Urbanization: The Rise of the Elysium City. Journal of Economics and Political Economy, 4(1), 1-13.

Norman, D. A. (1984). Stages and levels in human-machine interaction. International Journal of Man-Machine Studies, 21(4), 365-375. doi:10.1016/S0020-7373(84)80054-1

Numan, J. H. (1998). Knowledge-based systems as companions: Trust, human computer interaction and complex systems (Doctoral dissertation). University of Groningen.

Ozguner, U., Stiller, C., \& Redmill, K. (2007). Systems for safety and autonomous behavior in cars: The DARPA Grand Challenge experience. Proceedings of the IEEE, 95(2), 397-412. doi:10.1109/JPROC.2006.888394

Parasuraman, A. (2000). Technology Readiness Index (TRI) a multiple-item scale to measure readiness to embrace new technologies. Journal of Service Research, 2(4), 307-320. doi:10.1177/109467050024001 
Parasuraman, A., \& Colby, C. L. (2001). Techno-Ready Marketing: How and why consumers adopt technology. Academic Press.

Parasuraman, A., \& Colby, C. L. (2015). An updated and streamlined technology readiness index: TRI 2.0. Journal of Service Research, 18(1), 59-74. doi:10.1177/1094670514539730

Park, C. W., Milberg, S., \& Lawson, R. (1991). Evaluation of brand extensions: The role of product feature similarity and brand concept consistency. The Journal of Consumer Research, 18(2), 185-193. doi:10.1086/209251

Perkola, W. (2017). Relevance classification of connected vehicles for short-lived distributed geospatial events. Kth Royal Institute of Technology. School of Computer Science and Communication.

Pires, P. J., \& Alves da Costa Filho, B. (2008). Fatores do índice de prontidão à tecnologia (TRI) como elementos diferenciadores entre usuários e não usuários de internet banking e como antecedentes do modelo de aceitação de tecnologia (TAM). RAC. Revista de Administração Contemporânea, 12(2).

PWC. (2016). Connected and Autonomous Vehicles: Revolutionising Mobility in Society. Society of Motor Manufacturers and Trades (SMMT). https://www.smmt.co.uk/wp-content/uploads/sites/2/Connected-andAutonomous-Vehicles-Revolutionising-Mobility-in-society.pdf

Rodrigues, J. C. (2018a). A imprevisibilidade aceitável na direção autônoma: Porque a ausência de respostas éticas não deve impedir a adoção de veículos autônomos. Anais. do X Congresso de Administração, Sociedade e Inovação (CASI). Petrópolis. RJ.

Rodrigues, J. C. (2018b). Autonomous cars, from "ownership" to "usage": how autonomous vehicles might corrupt automotive industry's business model. 26th Gerpisa Colloquium. São Paulo. SP.

Rose, G., \& Straub, D. (1998). Predicting general IT use: Applying TAM to the Arabic world. Journal of Global Information Management, 6(3), 39-46. doi:10.4018/jgim.1998070104

Santa Rita, L. P., de Araújo, A. C., de Paula, M. A., de Oliveira Lima, M., \& Viana Filho, J. C. (2010). Consumo de produtos e serviços inovadores: Aplicação do índice de prontidão para tecnologia. Revista Brasileira de Inovação, 9(1), 167-196. doi:10.20396/rbi.v9i1.8648997

Schulze, A., Paul MacDuffie, J., \& Täube, F. A. (2015). Introduction: Knowledge generation and innovation diffusion in the global automotive industry - change and stability during turbulent times. Industrial and Corporate Change, 24(3), 603-611. doi:10.1093/icc/dtv015

Sivak, M., \& Schoettle, B. (2015). Road safety with self-driving vehicles: General limitations and road sharing with conventional vehicles. Academic Press.

Smith, B. W. (2013). Human error as a cause of vehicle crashes. The Center for Internet and Society at Stanford Law School.

Souza, R. V. D. (2002). Prontidão para tecnologia do consumidor: aspectos emocionais da adoção de produtos e serviços baseados em tecnologia. Encontro Da Associação Nacional de Pós-Graduação E Pesquisa - EnANPAD, 27.

Souza, R. V. D., \& Luce, F. B. (2005). Avaliação da aplicabilidade do technology readiness index (tri) para a adoção de produtos e serviços baseados em tecnologia. Revista de Administração Contemporânea, 9(3), 121-141. doi:10.1590/S1415-65552005000300007

Taylor, J. W. (1974). The role of risk in consumer behavior. Journal of Marketing, 54-60.

Urmson, C., Anhalt, J., Bagnell, D., Baker, C., Bittner, R., Clark, M. N., \& Gittleman, M. et al. (2008). Autonomous driving in urban environments: Boss and the urban challenge. Journal of Field Robotics, 25(8), 425-466. doi:10.1002/rob.20255

Vallet, M. (2013). Survey: Drivers ready to trust robot cars. http://www.foxbusiness.com/features/2013/11/04/ survey-drivers-ready-to-trust-robot-cars.html

Vinuto, J. (2016). A amostragem em bola de neve na pesquisa qualitativa: um debate em aberto. Temáticas, (44).

Yağdereli, E., Gemci, C., \& Aktaş, A. Z. (2015). A study on cyber-security of autonomous and unmanned vehicles. The Journal of Defense Modeling and Simulation, 12(4), 369-381. doi:10.1177/1548512915575803 
José Carlos Rodrigues is a MSc. in Consumer behaviour; specialist in Digital Marketing/e-business, storytelling and technology impact on human behaviour. Over 20 years acting as a business executive at the digital / interactive business industry, 7 of which as Digital Products' Director at The Walt Disney Company, besides companies such as Hewlett-Packard, Ford, Bridgestone, Intel and Samsung, among others. Also acting as a professor at ESPM and Casper Libero universities. experiência no mercado digital / interativo, 7 dos quais como Diretor da Disney Interactive, além de passagens pela Hewlett-Packard e JWT, também é professor na ESPM, Faculdade Casper Libero e Business School São Paulo (Laureate International), além de autor de quatro livros sobre comportamento do consumidor e negócios digitais.

Mateus Ponchio received his Ph.D. degree in Marketing from the Getulio Vargas Foundation in Sao Paulo, Brazil (2006). In that same year, he was a visiting scholar at the University of Otago in Dunedin, New Zealand. In 2015, he was a visiting scholar at the Georgia State University in Atlanta, USA. Since 2008, Mateus has been working at Escola Superior de Propaganda e Marketing in Sao Paulo as professor of Consumer Behavior at the Postgraduate Program in Business. He has published in journals such as the Journal of Consumer Behaviour, Journal of Macromarketing, Journal of Marketing Management, Marketing Intelligence and Planning, International Journal of Bank Marketing, among others. 